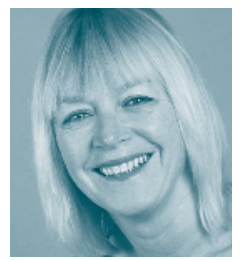

Eli Bøe,

universitetslektor,

Universitetet i Stavanger

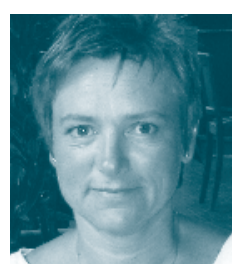

Bente Rossavik, sykepleier/studentkoordinator Stavanger universitetssykehus

\section{Lærer forskjellig på skole og i praksis}

\author{
Sykepleierstudenter legger mest vekt på det de lærer om legemidelhåndtering \\ i praksis til tross for at den ikke alltid er forskriftsmessig.
}

www.sykepleien.no

Les mer og finn litteraturhenvisninger på våre nettsider.

\section{Søkeord:}

\section{) Legemidler}

) Medisinhåndtering

> Pedagogikk

Sykepleierstudent

) Fokusgruppe
D et er et mål at sykepleierstudenter lærer legemiddelhåndtering på en forskriftsmessig og forsvarlig måte. For å nå dette målet er det viktig med et nært samarbeid mellom skole og praksisfelt. Studentene ønsker at sykepleiere i praksis skal samarbeide med skolen om praksisforberedende undervisning. De oppfatter at den måten de håndterer legemidler på i praksis er den beste, på tross av at kontaktsykepleierne ofte har innarbeidet vaner og uvaner og ikke er oppdaterte på de nyeste forskriftene for legemiddelhåndtering. Kontaktsykepleierne gir uttrykk for at de ofte føler seg usikre på veilederrollen.

\section{Hensikt}

Hensikten med denne studien er å belyse undervisningen $\mathrm{i}$ legemiddelhåndtering på skole og i praksis fra ulike perspektiver. Vi ønsker å fokusere på styrker og svakheter både ved skolens undervisningsopplegg og opplæringen i praksis. Målet er at studentene skal oppleve at teori og praksis er to sider av samme sak.

\section{Metode}

I april 2008 gjennomførte vi to fokusgruppeintervjuer, ett med en gruppe studenter og ett med en gruppe kontaktsykepleiere fra to forskjellige sengeposter på et sykehus. I intervjuene reflekterte informantene over studentenes læring av legemiddelhåndtering. Fem sykepleierstudenter i fjerde semester på bachelorutdanningen og seks kontaktsykepleiere deltok.

Intervjuguiden handlet om hva det innebærer å håndtere legemidler, om forutsetninger for og hindringer for læring, om overføring fra teori til praksis, om det delegerte ansvaret og om forbedringsmuligheter. Intervjuene ble foretatt før de nye Forskriftene for legemiddelhåndtering trådte i kraft 1.5.2008. Analysen resulterte i hovedkategoriene:

> Praksisforberedelsenes betydning for studentenes læring , Praksis som læringsarena

, Studenten som lærende , Kontaktsykepleierens rolle
Vi har presentert funnene i undersøkelsen som fritekst, men vi har brukt sitater fra studentene og kontaktsykepleierne for å illustrere viktige poenger. Vi håper at funnene kan stimulere til videre arbeid med å dyktiggjøre studentene til forskriftsmessig og forsvarlig legemiddelhåndtering.

\section{Praksisforberedelser}

Praksisforberedelsene utgjør en viktig del av utdanningens program (1). Skolens sykepleielaboratorium har et medisinrom som er tilnærmet identisk med de forhold studentene møter i praksis. Ferdighetstrening og simulering utgjør en vesentlig del av undervisningen. Studentene betrakter praksisforberedelsene som viktige, de får prøve seg i trygge omgivelser og det oppleves som lærerikt. De er likevel mest opptatt av hva som blir gjort i praksis: «Forberedelsene er for så vidt viktige, men av og til føler jeg at sånn er det viktig å gjøre på skolen, men i praksis så gjør vi det på en annen måte. Det kan skyldes evnen til å se at det finnes forskjellige måter å gjøre ting på, kanskje. Men det er som du sier at når du har vært på laben så har du fått med prosedyren og dermed har du en knagg å henge ting på.»

Det virker som studentene opplever at skole og praksis er to forskjellige læringsarenaer med forskjellige mål. Studentene opplever med andre ord et gap mellom teori og praksis. Aktivitetene på skolen knyttes til arbeidskravet i legemiddelregning og praktisk muntlig eksamen, og oppfattes ikke som forberedelser til praksis: «Du skal forholde deg til skolen og dens læremåte, det har jo med eksamener å gjøre. Og så går du på jobb, og der har de sin måte og sine rutiner.»

\section{Ønsker mer praksis}

Så selv om praksisforberedelsene gir studentene knagger å henge kunnskapen på, ønsker de mer praksis, og de vil ha sykepleiere fra praksis inn i skolens sykepleielaboratorium: «Ja, jeg tenker at det vi lærer på skolen er grunnsteinen i det vi skal bygge videre på. Men det som hadde vært fint, var om en fra sykehuset kom og viste oss i stedet for en lærer som 
hadde vært borte fra tingene i mange år. Det er kommet nye og enklere måter å gjøre ting på og også mer avanserte måter å gjøre ting på. Slik at vi kunne fått lære det i de obligatoriske timene i sykepleielaboratoriet.»

Sykepleielærerne har i lang tid følt seg presset av studentenes forventninger på den ene siden og myndighetenes krav om akademisk kompetanse på den andre. Ifølge studentene i vår undersøkelse, har lærerne opprettholdt sin faglige teoretiske kompetanse, men ikke trygghet i praktisk sykepleie (3). Det kan derfor synes som et dilemma når en av kontaktsykepleierne sier: «... at hvis vi har en student, og hun spør meg hvordan jeg gjør det, og så sier jeg det, og så sier hun at på skolen så har vi lært det sånn, og da sier jeg at hun må gjøre sånn som hun har lært.»

\section{Uvaner i praksis}

En student uttrykker det slik: «Men de er veldig interessert i å høre hva vi har lært. Og så sier de: Da gjør vi det sånn. Det er viktig å få erfaring fra dem som er i praksis ... men de endrer ikke for det ...»Vi tolker disse utsagnene som at kontaktsykepleierne viser respekt for den kunnskapen studenten har med seg fra skolen. Sykepleierne kan si at «det er jo dere som har den nyeste kunnskapen». De har selv «lagt seg til uvaner», men det kan virke som de vil fortsette med uvanene i stedet for å endre praksis. En studie viser at (4) nyutdannede sykepleiere som er nyansatte på sykehuset, opplever at de etter to år i yrket er blitt en del av systemet. De forsøker å holde fast på sine idealer om forskriftsmessig medikamenthåndtering, men: «de er nødt til å forandre på noe, fordi de har sett og opplevd virkeligheten».

Samarbeid med sykepleiere i praksis kan etter vår oppfatning,

\section{Det er viktig å få erfaring fra dem som er i praksis.}

bidra til større grad av samsvar og gjenkjennelse hos studentene når de møter praksis. Erfaring viser at sykepleiere som trekkes inn i praksisundervisning tar med seg gode vaner og «beste praksis» tilbake på post. Konsekvensen kan da bli en mer bevisst holdning og økt kunnskap om legemiddelhåndteringspraksis i møtet med pasienten.

\section{Legemiddelregning}

Studentene ønsker mer kunnskap om legemidler før de kommer ut i praksis. De skulle også ønske at de visste mer om omfanget av synonympreparater og at de hadde lært å bruke Felleskatalogen bedre. De trenger lang tid til å sette frem medikamenter, i tillegg til at det ikke alltid kommer frem på kurven at det er brukt synonympreparater - noe som i seg selv er en studie verd.

Skolen bruker store ressurser på at studentene skal bli dyktige til å regne ut pasientdoser. Vi mener at dette er nødvendig. Å trene på utregning av pasientdoser må også prioriteres når studentene er ute i praksis. Kontaktsykepleierne på sin side sier at behovet for legemiddelregning på postene ikke er så stort. Og at det som er, er relativt enkelt. Det er interessant at sykepleierne opplever omfanget av nødvendige regneoperasjoner som lite. En studie ved St. Olavs Hospital (5), påviste for eksempel et doseavvik (for høy eller for lav dose) på over 80 prosent av i alt 237 meldte avvik

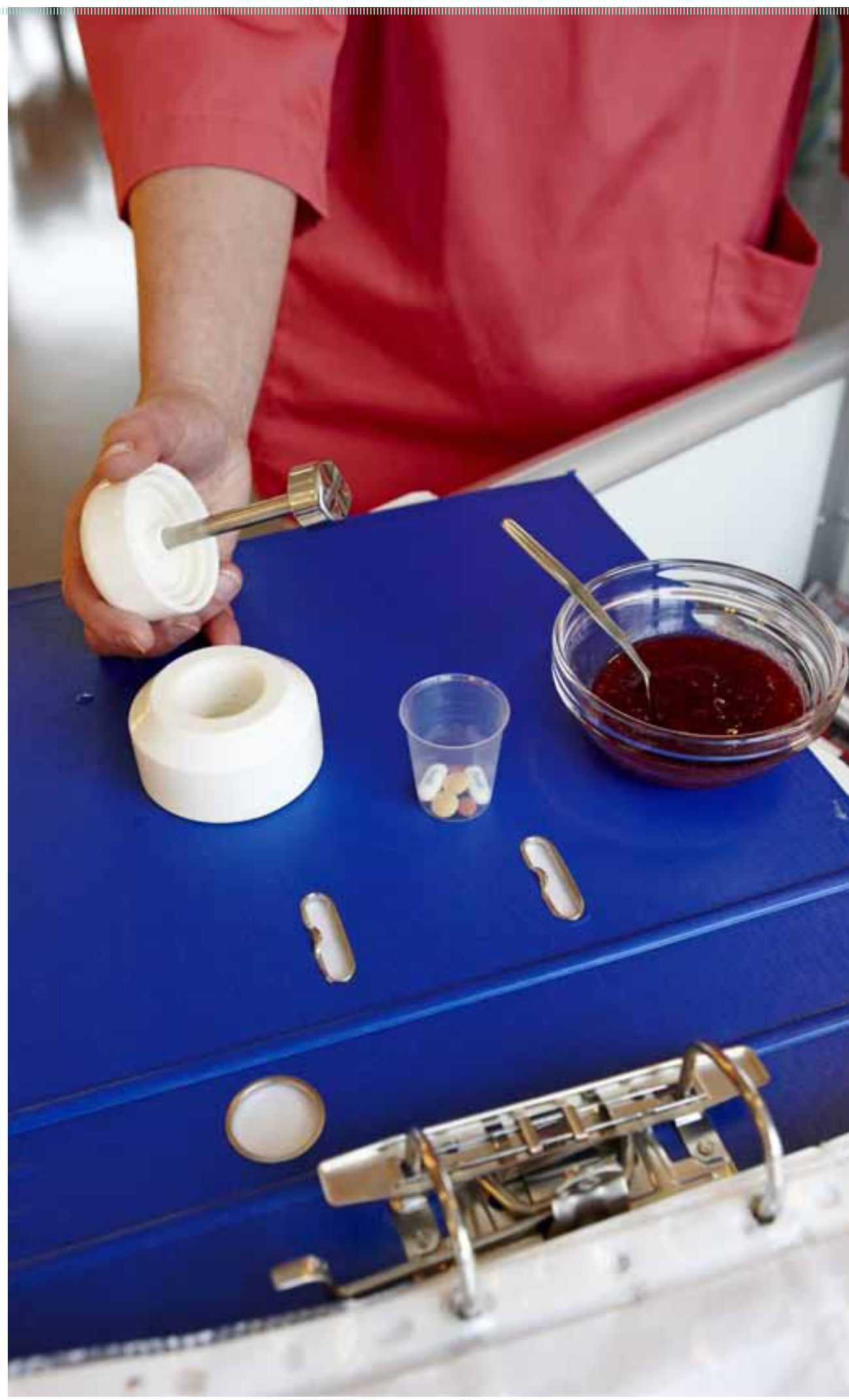

LAERER MEDISISNHÅNDTERING: Praksisforberedelser og praksis gjør det mulig for studentene å prøve og feile uten at det får fatale konsekvenser. Foto: Erik M. Sundt

mellom 2002 og 2007. Vi vet samtidig at det er store mørketall (6).

\section{Læringsbarrierer}

Studentene møter mange læringsbarrierer i praksis (7). Mangel på systematisk opplegg for og begrenset tid til læring, er de to største barrierene. Men forhold som dårlig organisering og lav bemanning på postene oppleves også som negativt: «Vi må få lov til å tre ut av pleien og gå inn på medisinrommet og gjøre sånne ting. Jeg vet at her er det også ymse praksis rundt forbi, vi er jo heldige. Jeg tror ikke de alltid kommer på at det kan være 〈kult〉 
å gå inn og hente to Paracet. He, he, det kan virke hverdagslig, men det er en del av læringen.»

Kontaktsykepleierne sier blant annet følgende om å ha studenter i praksis og hvilke muligheter de har for å gi veiledning: «I begynnelsen tok jeg studentene med på alt jeg skulle ha gjort. Til slutt fant jeg ut at det kunne jeg ikke. Det blir bare kaos i hodet av det. Så har det blitt sånn at jeg sier at nå kan du konsentrere deg om det mens jeg gjør fire andre ting. Og så kan du (studenten) lese på prosedyrene imens. Det går.»

Dette kan tyde på at kontaktsykepleierne mangler veiledningskompetanse, noe som også underbygges i en studie av Rossavik (8). I en rapport fra en av studentpostene ved Stavanger universitetssykehus (9) var en av konklusjonene at studentene lærte mest ved å bli integrert i arbeidsfellesskapet og få ansvar.

\section{«Jeg vil bli som deg!»}

Kontaktsykepleierne har ulik bakgrunn og kompetanse, og de er viktige rollemodeller for studentene. Selv opplever de at den største barrieren ved å være nyutdannet er å være alene om ansvaret for legemiddelhåndteringen (4). Svært mange har heller

\section{Det vi lcerer på skolen er noe helt annet enn det vi ser ute i praksis.}

ikke formell veilederkompetanse. Dette er en utfordring både for skolen og for praksis. På tross av at kontaktsykepleierne opplever denne usikkerheten, dårlig praksis og lite gunstige veiledningsforhold, ønsker studentene likevel å «bli som dem»: «Jeg synes praksis og skole er helt forskjellige ting, jeg. Helt forskjellig! Det vi lærer på skolen er noe helt annet enn det vi ser ute i praksis. Du skal forholde deg til skolen og dens læremåte, det har jo med eksamener å gjøre. Og så går du på jobb og der har de sine måter og sine rutiner. Jeg må jo ærlig innrømme at jeg tenker at det er de som har erfaringen, det er de som jobber her som gjør det slik jeg har lyst til å gjøre det.»

Heldigvis er det også eksempler på gode læresituasjoner. Kontaktsykepleierne beskriver veiledningen slik: «... vise at det er mange måter å gjøre ting riktig på ... spør hva de har lært, legge til rette for valg, trene på ulike måter for å finne hva som er det beste for pasienten ... være med dem fra begynnelse til slutt, ikke si alt, spørre om de har tenkt riktig. Konkludere, være assistent, gå igjennom sammen, ser hva som blir galt ... be dem om å være bevisst, hvorfor de gir det de gir.»

\section{Prøve og feile}

Studentene blir oppfordret til å stå alene på medisinrommet eller jobbe flere studenter sammen og gjerne flere dager etter hverandre. Slik får de muligheten til å trene på ulike administrasjonsmåter og til å slå opp i Felleskatalogen.

En av studentene fremhever betydningen av å prøve og feile i trygge omgivelser: «Ja, jeg skulle skylle med $\mathrm{NaCl}$ i en treveiskran og fant ikke helt fram - fikk den ikke helt inni. Så måtte jo kontaktsykepleier si til slutt at der er jo propp på (latter). Ja, du vet en er jo helt stresset. Ja, jeg må jo ta av proppen. Og kontaktsykepleier spør om er nå sprøyten steril? Nei ... Hun så jo hele tiden hva som skjedde, men lot meg prøve og lære av mine feil. Jeg tror vi lærer mer av å gjøre feilen. Der gikk en sprøyte i bosset, men jeg har ikke gjort det igjen. Det var en god måte å lære på - har du vært borti noe så ikke bruk sprøyten. Det var ganske flaut akkurat da, men jeg lærte av det. Jeg synes det var imponerende av henne å la meg gjøre det. Ja, klare å la være å si noe.»

\section{Konklusjon}

Et styrket samarbeid mellom skole og praksis synes nødvendig. Det må fortsatt satses på forberedelser som sikrer «praksisnærhet» og erfaringsbasert kompetanse. Studentenes læringskompetanse og evne til refleksjon over erfaringene med legemiddelhåndtering, enten de er i sykepleielaboratoriet eller i «den virkelige verden», må utvikles. Her fremstår både læreren og kontaktsykepleieren som viktige veiledere i prosessen, enten studenten er på skolen eller i praksis. Kontaktsykepleiere kan på tross av «egne uvaner» gi god sykepleie til den enkelte pasient. Det er likevel en forutsetning at den enkelte sykepleier håndterer legemidler til den enkelte pasient forskriftsmessig, godt sykepleiefaglig forankret og ut fra aktuelle retningslinjer og prosedyrer. Oppfyllelsen av kravene er også et ledelsesansvar. Det ligger utfordringer her med å tilrettelegge for studentens læring av legemiddelhåndtering i praksis. Kontaktsykepleiers veiledningskompetanse er nødvendig, men ikke alltid tilstrekkelig. Kontaktsykepleier må få mulighet til å styrke egen veiledningskompetanse, for eksempel ved å delta på veilederkurs eller i veiledningsfellesskap. Det må sikres et tydelig veiledningsopplegg for studenten som også har aksept i miljøet. Et sterkere samarbeid med lærer og praksisfelt anser vi som svært betydningsfullt.

At studentene "glorifiserer» praksis og sykepleierne sier at studentene må gjøre som de har lært på skolen, men selv fortsetter sin egen praksis, er interessante funn. IIII 